\title{
Entrepreneurial lean thinking for sustainable business modeling: a workshop design for incumbent firms
}

\author{
E. J. Schwarz · P. Gregori' • I. Krajger · M. A. Wdowiak \\ Received: 22 July 2019 / Revised: 30 July 2020 / Accepted: 17 December 2020 / Published online: 8 January 2021 \\ (c) The Author(s) 2021
}

\begin{abstract}
In times of increasing concerns and extensive political debates about social and environmental problems, incumbent firms are obliged to reduce their negative environmental impact by implementing sustainable business model innovation. Yet, realizing more sustainable business model variants entails several complexities and associated challenges that need to be overcome. To support this task, this article takes an entrepreneurship perspective on sustainable business model innovation and combines literature of business models and entrepreneurial lean thinking (ELT). In doing so, it derives a workshop design grounded in contemporary theory with state-of-the-art tools and methods. The workshop is framed as a stage-gate process facilitating the notions of ELT with iterative cycles of 'create, test, and improve' and spans the phases of opportunity identification, opportunity evaluation, opportunity development through sustainable business model design, and decision of opportunity exploitation. The article shows that ELT is an appropriate yet underutilized approach for sustainable business modeling. Further, it discusses how the workshop supports opportunities and mitigate pitfalls of ELT for sustainable business modeling. As such, the findings have theoretical implications for the intersection of sustainability and lean approaches in innovation research as well as implications for practitioners by providing a comprehensive framework to support sustainable business model innovation.
\end{abstract}

Keywords Sustainable Business Models · Entrepreneurial Lean Thinking · Business Model Innovation · Workshop Design $\cdot$ Stage-Gate Model $\cdot$ Sustainability

\section{Introduction}

Humanity is confronted with substantial social and environmental challenges such as social inequality, poverty, climate change, or deforestation that play a pivotal role in the present scientific and political discourse (Sneddon et al. 2006; Dangelico and Pontrandolfo 2015; Joyce and Paquin 2016; Gast et al. 2017). Supranational agreements call to action and emphasize a transformation of business practices to achieve our common goal of a more sustainable development (European Commission 2013; United Nations 2015). As such, established and new enterprises are encouraged to contribute to the much needed radical changes by implementing business models that go beyond economic value and create social and environmental value as well (Schal-

P. Gregori

patrick.gregori@aau.at

1 Department of Innovation Management and Entrepreneurship, University of Klagenfurt, Universitaetsstraße 65-67, 9020 Klagenfurt, Austria tegger et al. 2016; Lüdeke-Freund and Dembek 2017). To be able to confront the complex and dynamic socioenvironmental changes, contribute to sustainable development, and fulfill legal requirements, companies need a way to efficiently implement sustainable innovation along the business model in a timely matter (Bocken et al. 2016; Kurucz et al. 2017; Weissbrod and Bocken 2017).

However, a majority of established enterprises refrain from innovating their business models towards more sustainable variants, have slow progress towards sustainability, and are less ambitious regarding their social and environmental goals than new ventures (Hockerts and Wüstenhagen 2010; Sommer 2012; Baumgartner and Rauter 2017; Ritala et al. 2018). This inertia is potentially related to the complexities, uncertainties, and challenges associated with developing and implementing coherent sustainable business models (Palzkill and Augenstein 2017; Evans et al. 2017). Scholarly work argues that sustainable business models need to follow social, environmental, and commercial logics that each have their own values, practices, and goals that are difficult to reconcile (Laasch 2018; Gregori and Holz- 
mann 2020). In addition, firms are often confronted with a deadlocked mindset, a reluctance to commit resources to sustainable innovation, and are overwhelmed by the complex integration of internal and external stakeholder in the innovation process (Stubbs and Cocklin 2008; Chesbrough 2010; Boons and Lüdeke-Freund 2013; Evans et al. 2017; Lüdeke-Freund and Dembek 2017).

Research suggests that sustainable entrepreneurs innovate differently and that incumbent firms can learn from entrepreneurial approaches towards innovation (Phan et al. 2009; Keskin et al. 2013, 2020). Entrepreneurial lean thinking (ELT) emerged as a way to guide innovation processes in uncertain and complex environments in corporate contexts (Humble et al. 2014; Owens and Fernandez 2014). Through constant feedback loops of creating, testing, and improving of innovative solutions, uncertainty can be reduced, which leads to more flexible and faster implementation of innovations (Ries 2011; Eisenmann et al. 2012; Blank 2013a). Due to this advantages, researchers recognize the potential of ELT for sustainable business modeling (Bocken and Snihur 2019). Indeed, first empirical studies dealing with the implementation of ETL in the context of sustainable business model innovation show promising results but also call for further systematic integration to enable practical implementations (Weissbrod and Bocken 2017; Baldassarre et al. 2017). To further develop the potential of ELT for sustainable business modeling, we tie insights from entrepreneurship and sustainable business model research and integrate them into a comprehensive workshop design with state-of-the-art tools and methods.

This article contributes to the novel field of ELT as an approach to innovate business models towards sustainability. First, the article lays out the theoretical foundations of sustainable business models as well as ELT and identifies current challenges of business model innovation for environmental sustainability. Second, based on the theoretical foundation, we provide a comprehensive workshop design for sustainable business modeling. Third, we discuss potential opportunities and drawbacks of the ELT approach for sustainable business model innovation and how the workshop can facilitate identified advantages and mitigate drawbacks. The article provides theoretical and practical implications and discusses limitations as well as avenues for future research.

\section{Theoretical background}

\subsection{The componential approach to business models}

A business model provides a conceptualized overview of the way in which "the business enterprise responds to and delivers value to customers, entices customers to pay for value, and converts those payments to profit through the proper design and operation of the various elements of the value chain" (Teece 2010, p. 191). Although discussions about the terminology concerning business models remain, a growing body of literature postulates that they are comprised of value propositions, value creation processes, and value capturing mechanisms (Bocken et al. 2014; Foss and Saebi 2017; Holzmann et al. 2017). Following such an approach we posit that a business model is constituted by four components: the value proposition, value creation architecture, customer interface and a revenue mechanism (Schwarz et al. 2013; Boons and Lüdeke-Freund 2013).

A value proposition is considered as the core component of every business model and describes the value a potential customer receives with the company's offer respectively the promise of a distinct value (Osterwalder and Pigneur 2010; Teece 2010). The value creation architecture is dedicated to the question of how the company is to create the value in the form of products or services. This component is comprised of the resources as well as key activities needed to realize the product in form of a market offering (Osterwalder et al. 2005). The customer interface determines how the services are communicated and distributed and includes an assessment of the target groups and the elaboration of distribution and communication channels (Osterwalder et al. 2005; Osterwalder and Pigneur 2010). The revenue mechanism describes the interplay of revenues and costs and lays the focus on how the value created for the stakeholders can be returned to the company in the form of economic earnings. For the company, this component is a central element of its business model, as it ensures the continued existence of the company in the long term (Teece 2010).

\subsection{Sustainable business models and their challenges}

Previous business model research mainly applied a purely commercial perspective to analyze how companies create and capture value (Massa et al. 2017). These studies defined the business model as the design and operation of businesses that provide appealing solutions that entice customers are willing to pay for and the conversion of this payment streams into profit (Amit and Zott 2001; Teece 2010). The focus on financial aspects, however, has been scrutinized by the growing research on sustainable business models that views businesses as important contributors to a more sustainable development (Boons and Lüdeke-Freund 2013; Lüdeke-Freund and Dembek 2017). As such, sustainable business models entail a broader notion of value that goes beyond financial aspects and also considers socioenvironmental value (Birkin et al. 2009b; Schaltegger et al. 2016; Upward and Jones 2016; Elkington and Upward 2016). 
Transforming companies towards sustainability often implies radical change (Evans et al. 2017). The innovation type of business model innovation has been linked to innovation processes for sustainability (Hansen et al. 2009; Boons and Lüdeke-Freund 2013) because it provides a comprehensive view of the whole business offering the possibility for more radical innovations that affect all functional areas of the company (Osterwalder et al. 2005; Teece 2010). Yet, this form of innovation is challenging due to the broader notion of value and the need to consider sustainability aspects in each component of the business models (Birkin et al. 2009b; Boons and Lüdeke-Freund 2013; Evans et al. 2017). Research argues that social, environmental, and commercial aspects follow their own logic, each with their own institutionalized values, practices, and goals (Laasch 2018). The profit maximization and the focus on financial gain of the commercial logic can stand in harsh contrast to environmental and social values such as preserving nature and waste reduction or the empowerment of people. Because of these inherent tensions and contradistinctions of the logics of sustainability, simultaneous creation of profits and socioenvironmental value is difficult to realize through coherent business models (Davies and Chambers 2018; Gregori et al. 2019; Gregori and Holzmann 2020). Furthermore, established firms are often confronted with a mindset that hinders the implementation of sustainable innovations and, in an related issue, there might be a reluctance concerning the resource allocation towards sustainable business model innovation (Birkin et al. 2009a; Evans et al. 2017). Sustainable business models should exceed a mere customer focus and take a multidimensional approach to stakeholders making the management of stakeholder relationships a complex issue that requires extra effort as well (Stubbs and Cocklin 2008; Keskin et al. 2013; Upward and Jones 2016).

\subsection{Entrepreneurial lean thinking}

Entrepreneurial lean thinking originates from the rich history of the lean paradigm (Sugimori et al. 1977; Ghezzi and Cavallo 2020), and transferred concepts of lean manufacturing into the start-up context (Ries 2011). Notably, it was introduced to the field of innovation and entrepreneurship in the early 2010s and initially offered an alternative approach for young firms focusing on experimentation and learning instead of formal business planning (Ries 2011; Blank 2013a). Current literature argues, however, that also established large companies can benefit from the concept of ELT in a similar vein, allowing for faster and more flexible innovation processes, which are increasingly important in uncertain and dynamic environments (Burgelman 1983; Humble et al. 2014; Owens and Fernandez 2014).

ELT builds upon the idea of customer discovery proposed by Blank (2013b), highlighting the iterative process

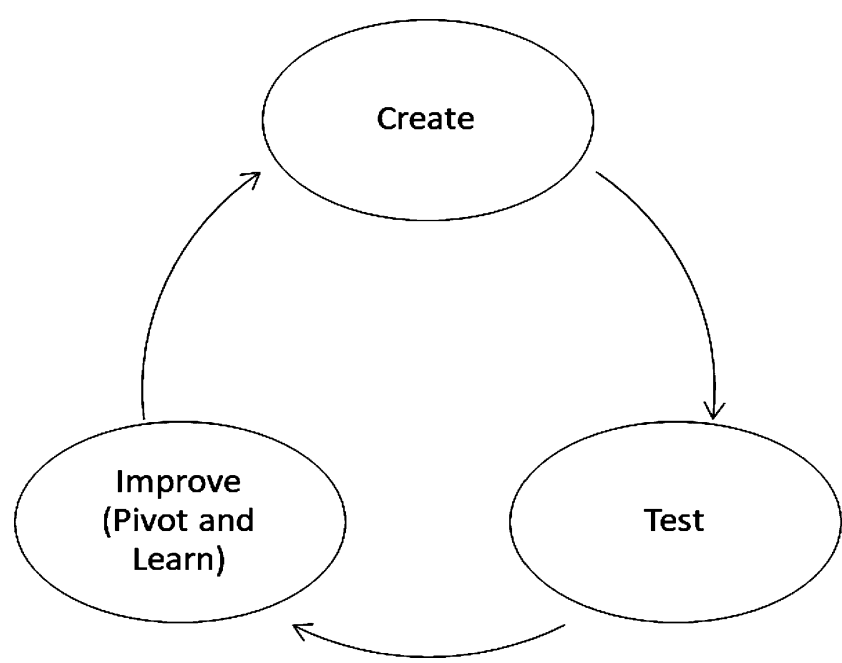

Fig. 1 A generic representation of entrepreneurial lean thinking. (Source: own illustration based on Ries 2011)

of pivots, failure, and learning. One of the major concepts of this movement is the experimental testing of pre-formulated falsifiable hypotheses through minimum viable products, which describe the "smallest set of activities needed to disprove a hypothesis" (Eisenmann et al. 2012, p. 1). This hypothesis-driven approach attaches more importance to experimentation for value opportunities than to rich planning (Blank 2013a). As such, it stresses the development of creative solutions that are tested and improved through direct market feedback in an iterative way (Ries 2011; see Fig. 1 for a graphical representation). Hypothesis testing is thereby not used in a traditional scientific sense. Entrepreneurs are rather formulating assumptions (e.g., the new product for our target group will increase the sales by $5 \%$ ), which are then evaluated by scanning the environment and collecting information (e.g., interviews with customers of that target group). Entrepreneurs are thus encouraged to develop an educated guess about these assumptions that support more accurate judgement for subsequent decisions. While testing a hypothesis, as for example newly designed business model components, the innovator or entrepreneur has the possibility to persevere with the current notion, pivot and therefore change parts of the idea or abandon the notion altogether (Ries 2011; Eisenmann et al. 2012). Therewith, ELT enforces the principle of customer pull that aims to reduce services, products or business practices for which there is no demand (Eisenmann et al. 2012). The principles of iterative testing and experimentation aims to prevent the waste of the time, passion, and skills of individuals (Ries 2011).

Due to its aforementioned characteristics, ELT can provide an efficient approach for experimentation in uncertain environments that is needed to trigger transitions towards sustainability (Bocken and Snihur 2019). The intersection 
of ELT and sustainable business model innovation, however, is still in its infancy (Weissbrod and Bocken 2017). While the volume of research on tools and methods for sustainability-oriented business model innovation has been growing significantly in recent years (Lüdeke-Freund and Dembek 2017), only a handful of articles integrate the ELT approach as a way to develop more sustainable businesses. For example, the entrepreneurial lean approach has successfully been used to develop value propositions for sustainable business models (Baldassarre et al. 2017). Yet other studies also indicate drawbacks as the application of ELT is not trivial and a lack of knowledge in this regard can hamper innovation processes (Weissbrod and Bocken 2017). Hence, there are calls for more inquiries concerning further elaborations on the practical intersection and processual implementation of ELT in the context of business modeling to gain a deeper understanding of its advantages and drawbacks (Weissbrod and Bocken 2017).

\section{Method}

We developed the framework for the workshop design in several steps: First, we conducted an analysis of literature on sustainable business models gaining in-depth insights of the current state of the field. This led us to identify the need for further work on tools and methods that support the development of sustainable business models and business model experimentation (Weissbrod and Bocken 2017; Lüdeke-Freund and Dembek 2017; Bocken and Snihur 2019). We identified ELT as a potential approach for business model experimentation (Baldassarre et al. 2017) and derived the overall aim of this article to design a workshop that facilitates sustainable business modeling through ELT.

Second, we divided the workshop into separate sessions and defined these objectives based on entrepreneurship literature. Accordingly, the entrepreneurial process is built around the concept of opportunities that are identified, evaluated, developed, and exploited (Shane and Venkataraman 2000; Hindle 2010; Moroz and Hindle 2012; Belz and Binder 2015). Each of these stages of (analysing) entrepreneurial opportunities has its own objective. Opportunity identification refers to the recognition of unmet needs and ineffective use of resources that provide the foundation for the creation of new value (Ardichvili et al. 2003; Cohen and Winn 2007). Opportunity evaluation seeks to assess the worth of the opportunity in relation the external environment (Hindle 2010; Tomy and Pardede 2017). Opportunity development refers to the process where the opportunity is more precisely defined and transferred into a business model (Ardichvili et al. 2003) and opportunity exploitation considers the realization of the opportunity on the market (Shane and Venkataraman 2000). Consequently, we designed the workshop according to these four phases and their inherent objectives: opportunity identification, opportunity evaluation, opportunity development through business model design, and reflection and decision of opportunity exploitation. All these workshop sessions are described in detail in the next section.

Third, we combined these phases systematically through a stage-gate process. Stage-gate processes were introduced in the 1980s US manufacturing industries for product development purposes based on an in-depth case study of successful intrapreneurs (Cooper 2014). Since then several improvements have changed the application and appearance of this method (Nepal et al. 2011). Typically, the method consists of several context-based stages that are separated by so-called 'gates', which act as control instances of the innovation process. Gates are checkpoints that determine the course of the subsequent development and are conflated with distinct deliverables or outcomes that must be reached at that point (Cooper 1990; Cooper et al. 2002). This approach aims to increase business effectiveness such as higher quality products in less time and with fewer resources and works especially well when projects are dominated by quality considerations (Yadav et al. 2007; Gremyr and Fouquet 2012). Recent developments of the stagegate process acknowledge the integration of entrepreneurial lean principles within the framework (Cooper 2014; Tesch et al. 2017). As opposed to earlier concepts, which lacked the important feedback iterations and learning within the innovation process (Nepal et al. 2011), more contemporary variations deliberately promote "multiple spirals or iterations of development that permit experimentation with users" and facilitates experimentation "encouraging project teams to fail often, fail fast, and fail cheaply" (Cooper 2014, p. 122). This opens stage-gate innovation models for the entrepreneurial lean principles, which focus on the importance of hypothesis-driven experimentation and iterative design with direct market feedback and learning to exploit new value opportunities (Ries 2011; Blank 2013a).

Fourth, we conducted a literature search to identify tools and methods that support each of the objectives of the phases. As a starting point, the Web of Science Core Collection was used to search for tools in context of sustainable business models (search terms: "sustain*" AND "business model*" AND "tool*"). Based on this initial overview and screening of articles, we used backwards citation search exploring the references of articles and the publication lists of prominently presented authors. We identified tools that support the objective of the workshop phases and are flexible and easy to use to be in compliance with the entrepreneurial lean principles of create, test, and improve. Moreover, we analyzed additional articles that used and tested these tools. The chosen concepts and tools, their sources and objectives, 
Table 1 Concepts and tools used for the framework and workshop design. (Source: own illustration)

Concept/ Sources and objective $\quad$ Exemplary applications and empirical tests $\quad \begin{aligned} & \text { Application in the context of the work- } \\ & \text { Tool }\end{aligned}$

Tool

Stage- $\quad$ Structured approach to optimize gate innovation processes for higher

process efficiency and quality (Cooper 1990, 2014; Cooper et al. 2002)
A study of 272 firms with provides empirical support for the notion that the use of stageand-gate-type systems fosters innovation program performance (Schultz et al. 2018)
Sustain- Canvases visually represent the able elements of a business, how they Busi- are interconnected, and how they ness impact value creation (Osterwalder Canvas and Pigneur 2010; Schwarz et al. 2013) Canvases can be used for creatively engaging with business model innovation for sustainability (Upward and Jones 2016; Joyce and Paquin 2016)

Value Value mapping assists companies Map- in understanding the current value ping proposition and to analyze sustainable value creation opportunities from a multi-stakeholder perspective (Bocken et al. 2013, 2015)

Value

uncap-

tured

per-

spec-

tive

The value uncaptured perspective provides a framework to understand negative socioenvironmental effects of the current business model, to identify uncaptured value in a systematic way, and to derive novel value opportunities (Yang et al. 2017)

PESTEL PESTEL helps to address and study Analy- the exogenous factors of the wider sis environment that affects the business (Sammut-Bonnici and Galea 2015) and has been suggested as a way to analyze the macro environment of sustainable business models (Bocken et al. 2013; Hope 2018)

Sustain- Business model archetypes provide able assistance to shape business model Busi- transformation towards sustainabilness ity in supporting the exploration of Model new ways to create and deliver susArchetype tainable value and the realization of opportunities (Bocken et al. 2014)
A study with of 271 teams in cleantech accelerator program showed that those teams using business model canvases performed better (Ladd 2018)

Business model canvases in the sustainability context have been tested in consulting, organizational workshops, and university courses. They support the effective communication of the current business model and the creative exploration of potential innovations (Joyce and Paquin 2016)

Developed through workshops with 131 participants in several industries such as clothing, retail, automotive, etc. (Bocken et al. 2013) Tests in workshop designs with a total of 35 students, 29 practitioners, and 7 researchers support the potential benefits of value mapping for stakeholder inclusion, understanding the current value proposition, identification of missed value, etc. (Geissdoerfer et al. 2016)

Developed and validated through six case studies (25 interviews, documents, workshops, observations, etc.) with 56 participants (Yang et al. 2017)

Successfully applied to identify the potential for value creation in a case study of a municipal waste management company (Zacho et al. 2018)

Used as a supporting tool in several sustainable business model workshops for start-ups, small- and medium-sized enterprises, and multinational companies as well as for education and teaching material (Rana et al. 2017)

Derived from literature and case studies, successfully tested in student and industry workshops to stimulate creative thinking (Bocken et al. 2014, 2015; Geissdoerfer et al. 2016) Sustainable business model archetypes, for example, have been used to categorize and trace the trajectory of business model transformations of S\&P 500 firms (Ritala et al. 2018)
Systematic combination of the workshop phases based on the entrepreneurial process

Deliberate promotion of iteration spirals that allow for experimentation in the innovation process intersecting with entrepreneurial lean thinking (Cooper 2014). Adjusted to emphasize the lean principles of creating, testing, and improving in each phase and introducing pivots at the gates

Tool to formalize current state of the company (setting the stage in session 1) and flexible experimentation tool to develop and to integrate value opportunities (session 3)

Adjusted to emphasize socioenvironmental balance and adding guiding questions for each component

Engaging and easy to use format to support group discussions and testing (Bocken et al. 2013)

Tool to identify the current state of value capture, value missed, and value destroyed to derive novel value opportunities (session 1)

Tool to identify relevant stakeholders and their relation to the current state of value creation (session 1)

Supporting mind-set for using the value mapping tool (session 1)

Providing an easily applicable checklist of forms of uncaptured value that trigger the identification of value opportunities (session 1)

Providing a structured framework to evaluate opportunities in context of macroenvironmental forces (session 2)

Creative inspiration and input for experimenting with opportunities through business model design (session 3 ) 
exemplary applications and empirical test as well as the application in the context of the workshop are presented in Table 1.

\section{An entrepreneurial lean approach for sustainable business model innovation: Conceptual framework and workshop design}

\subsection{Integration of entrepreneurial lean thinking}

The aforementioned concepts and tools have been integrated into a comprehensive workshop design (see Fig. 2). The notions of ELT are incorporated in the workshop design as follows: Each phase comprises three steps in an iterative cycle derived from lean thinking literature (Ries 2011; Eisenmann et al. 2012; Blank 2013a): create, test, and improve. In the first step 'create', problems are analyzed and solutions are developed. It is central to identify the key challenges, important stakeholders and technologies, advance the innovative sustainable business model and develop first potential solutions (prototypes) of future products or organizational designs. In the next step, called 'test', the previously developed assumptions and ideas are critically reviewed. In the last step, 'improve', feedback and test results are evaluated. It is about learning and using these lessons learned for business model development.

Moreover, the fundamental idea of pivoting is anchored at the milestones (gates) between the stages (M1-M4). At each of these milestones, one has to select one of the three available options for the idea or innovation: persevere, pivot, or perish. Our workshop process supports projects for sustainble innovation in identifying opportunities and risks at an early stage and correcting errors through external feedback. In line with the theoretical specifications of stage-gate and ELT (Ries 2011; Blank 2013a; Cooper 2014), the individual phases can be repeated and, if necessary, a change can be initiated.
There are several days between the workshop sessions named transition phases, where participants are encouraged to interact with real-life stakeholders (e.g., colleagues within the company, potential customers, suppliers, etc.) about their developments within the workshop. That facilitates stakeholder integration, which is needed for sustainable innovation processes (Stubbs and Cocklin 2008; Keskin et al. 2013, 2020). This encourages the strategic and appropriate utilization of knowledge outside and inside of the enterprise to foster information synergies in every aspect of the subsequent create, test, and improve cycles. This feedback is an integral part of the ELT concept (Ries 2011). The constant testing and feedback reduce wasted time as well as unnecessarily used resources, helps to identify uncaptured value and allows for experimentation (hypothesistesting) with first prototypes in the form of minimum viable products or new organizational designs (Blank 2013a).

Suitable methods and instruments are recommended for each phase, which are consistent with the lean approach. Table 2 gives a summary of the objectives, planned actions, and utilized tools in the individual sessions and transition phases of the workshop.

\subsection{Session 1-Opportunity identification}

The purpose of the first stage is to assess the current situation of the firm as well as to identify the sustainable opportunities one wants to follow up on in the next stages of the process. At the end of this phase, the participants should have a common understanding of the current business model employed and to derive the first testable hypothesis of potential opportunities for further engagement. In comparing the current situation with potential socioenvironmental value opportunities, the participants should also elaborate on the potential positive impact relative to the current business model. Value opportunities are defined as activities that can capture, create, and deliver new value to the firm and/or the stakeholders. For example, potential value that could be captured but has not yet been cap-

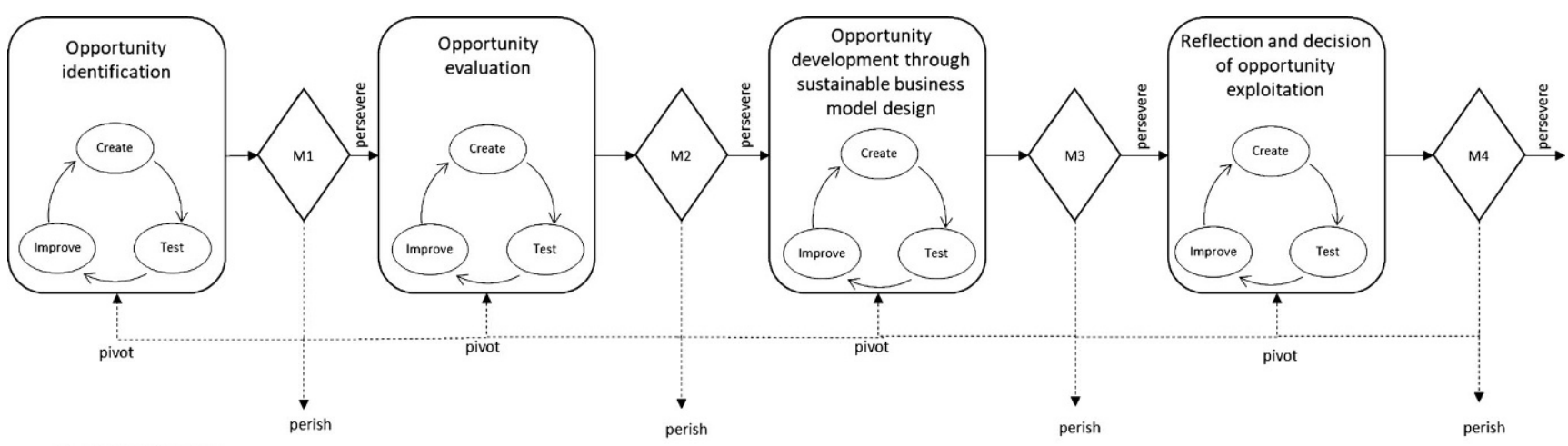

M1-M4: Milestones 1 to 4

Fig. 2 Workshop procedure for sustainable business model innovation based on entrepreneurial lean thinking. (Source: own illustration) 
Table 2 Overview of planned duration, actions, and tools in the workshop phases. (Source: own illustration)

Workshop sessions and transition phases

Session 1-Opportu- Transition nity identification phase I

$\begin{array}{ll}\text { Session 2-Opportu- } & \text { Transition } \\ \text { nity evaluation } & \text { phase II }\end{array}$

\begin{tabular}{lll}
$\begin{array}{l}\text { Session 3-Op- } \\
\text { portunity } \\
\text { development } \\
\text { through } \\
\text { sustainable } \\
\text { business model } \\
\text { design }\end{array}$ & $\begin{array}{l}\text { Transition } \\
\text { phase III }\end{array}$ & $\begin{array}{l}\text { Session 4- } \\
\text { Reflection } \\
\text { and decision } \\
\text { to exploit the } \\
\text { opportunity }\end{array}$ \\
\hline $\begin{array}{l}\text { Integrate value } \\
\text { opportunities } \\
\text { in the business }\end{array}$ & $\begin{array}{l}\text { Getting } \\
\text { feedback } \\
\text { from de- }\end{array}$ & $\begin{array}{l}\text { Final Presen- } \\
\text { tation }\end{array}$ \\
$\begin{array}{l}\text { Design of a co- } \\
\text { herent sustain- } \\
\text { able business }\end{array}$ & $\begin{array}{l}\text { makers } \\
\text { inside } \\
\text { montation }\end{array}$ \\
$\begin{array}{l}\text { the com- } \\
\text { decision } \\
\text { Decision at } \\
\text { milestone } 3\end{array}$ & pany & $\begin{array}{l}\text { concerning } \\
\text { the business } \\
\text { model in- } \\
\text { novation at } \\
\text { milestone 4 }\end{array}$ \\
& & milon
\end{tabular}

\begin{tabular}{|c|c|c|c|c|c|c|c|}
\hline $\begin{array}{l}\text { Objec- } \\
\text { tives } \\
\text { and } \\
\text { ac- } \\
\text { tions }\end{array}$ & $\begin{array}{l}\text { Assessing the current } \\
\text { state } \\
\text { Identify socioenviron- } \\
\text { mental value opportu- } \\
\text { nities for sustainable } \\
\text { business model inno- } \\
\text { vation } \\
\text { Establish a first set } \\
\text { of potential value } \\
\text { opportunities } \\
\text { Decision at mile- } \\
\text { stone } 1\end{array}$ & $\begin{array}{l}\text { Getting } \\
\text { feedback } \\
\text { inside the } \\
\text { company's } \\
\text { boundaries } \\
\text { (e.g. em- } \\
\text { ployees from } \\
\text { different } \\
\text { functional } \\
\text { areas) }\end{array}$ & $\begin{array}{l}\text { Assess the macro- } \\
\text { environmental con- } \\
\text { ditions to evaluate } \\
\text { hitherto identified } \\
\text { opportunities } \\
\text { Narrow down the } \\
\text { value opportunities } \\
\text { in relation to environ- } \\
\text { mental information } \\
\text { Decision at mile- } \\
\text { stone } 2\end{array}$ & $\begin{array}{l}\text { Getting } \\
\text { feedback } \\
\text { outside the } \\
\text { company's } \\
\text { boundaries } \\
\text { (customer, } \\
\text { suppliers, } \\
\text { political } \\
\text { actors, etc.) }\end{array}$ & $\begin{array}{l}\text { Integrate value } \\
\text { opportunities } \\
\text { in the business } \\
\text { model } \\
\text { Design of a co- } \\
\text { herent sustain- } \\
\text { able business } \\
\text { model } \\
\text { Decision at } \\
\text { milestone } 3\end{array}$ & $\begin{array}{l}\text { Getting } \\
\text { feedback } \\
\text { from de- } \\
\text { cision- } \\
\text { makers } \\
\text { inside } \\
\text { the com- } \\
\text { pany }\end{array}$ & $\begin{array}{l}\text { Final Presen- } \\
\text { tation } \\
\text { Final imple- } \\
\text { mentation } \\
\text { decision } \\
\text { concerning } \\
\text { the business } \\
\text { model in- } \\
\text { novation at } \\
\text { milestone } 4\end{array}$ \\
\hline Tools & $\begin{array}{l}\text { Sustainable Business } \\
\text { Model Canvas (setting } \\
\text { the stage) } \\
\text { Value Mapping } \\
\text { Value uncaptured } \\
\text { perspective }\end{array}$ & $\begin{array}{l}\text { Interviews } \\
\text { Questionnaires }\end{array}$ & PESTEL Analysis & $\begin{array}{l}\text { Interviews } \\
\text { Questionnaires }\end{array}$ & $\begin{array}{l}\text { Sustainable } \\
\text { Business } \\
\text { Model Canvas } \\
\text { (developing } \\
\text { tool) } \\
\text { Sustainable } \\
\text { Business } \\
\text { Model } \\
\text { Archetypes }\end{array}$ & $\begin{array}{l}\text { Interviews } \\
\text { Question- } \\
\text { naires } \\
\text { Designing } \\
\text { and } \\
\text { testing } \\
\text { of proto- } \\
\text { types }\end{array}$ & - \\
\hline
\end{tabular}

Table 3 Sub-Blocks and corresponding questions to the sustainable business model canvas. (Source: own illustration)

\begin{tabular}{|c|c|c|}
\hline Main component & Sub-blocks & Questions \\
\hline \multirow[t]{3}{*}{$\begin{array}{l}\text { Value } \\
\text { Proposition }\end{array}$} & Value & $\begin{array}{l}\text { What values does the company provide? Does the company provide socioenvironmental values } \\
\text { for their customers? }\end{array}$ \\
\hline & Product & What does the company offer? How sustainable is the product? \\
\hline & $\begin{array}{l}\text { Unique selling proposi- } \\
\text { tion (USP) }\end{array}$ & $\begin{array}{l}\text { What is the USP of the offer relative to the competitors? Will the sustainable-oriented efforts be } \\
\text { perceived by the relevant stakeholders? }\end{array}$ \\
\hline \multirow[t]{3}{*}{$\begin{array}{l}\text { Stakeholder } \\
\text { interface }\end{array}$} & $\begin{array}{l}\text { Communication chan- } \\
\text { nel }\end{array}$ & $\begin{array}{l}\text { Which channels can be used to contact the customer and relevant stakeholders? Which socioen- } \\
\text { vironmental information is communicated (e.g. eco-labels)? }\end{array}$ \\
\hline & Target group & What are target groups and what problems/demands do they have? \\
\hline & Distribution channel & How are the customers reached? What socioenvironmental impact does distribution have? \\
\hline \multirow[t]{3}{*}{$\begin{array}{l}\text { Value creation } \\
\text { architecture }\end{array}$} & Value chain & $\begin{array}{l}\text { What activities are needed to realize the value proposition? What are the critical sustainability- } \\
\text { related activities? }\end{array}$ \\
\hline & Internal activities & $\begin{array}{l}\text { What activities are conducted internally? What socioenvironmental impact do these activities } \\
\text { have (e.g. material/energy usage, pollution, social inequalities, etc.) }\end{array}$ \\
\hline & External activities & $\begin{array}{l}\text { What activities are outsourced to partners? Can partners provide the company's demanded envi- } \\
\text { ronmental standards? }\end{array}$ \\
\hline \multirow[t]{2}{*}{$\begin{array}{l}\text { Revenue } \\
\text { mechanism }\end{array}$} & Costs & $\begin{array}{l}\text { What costs do occur due to value creation and stakeholder interface? What costs are reduced by } \\
\text { a more sustainable production? (e.g. } \mathrm{CO} 2 \text { taxes, material savings due to reuse) }\end{array}$ \\
\hline & Revenues & $\begin{array}{l}\text { What revenues can be generated? Which additional revenues are generated by sustainable prod- } \\
\text { ucts? }\end{array}$ \\
\hline \multirow[t]{2}{*}{$\begin{array}{l}\text { Socioenvironmental } \\
\text { balance }\end{array}$} & $\begin{array}{l}\text { Socioenvironmental } \\
\text { impacts }\end{array}$ & $\begin{array}{l}\text { What are the socioenvironmental impacts of the product during production and usage (life-cycle } \\
\text { perspective)? }\end{array}$ \\
\hline & $\begin{array}{l}\text { Socioenvironmental } \\
\text { benefits }\end{array}$ & $\begin{array}{l}\text { What are the socioenvironmental benefits during production and consumption of the product } \\
\text { compared to former and competing products? }\end{array}$ \\
\hline
\end{tabular}




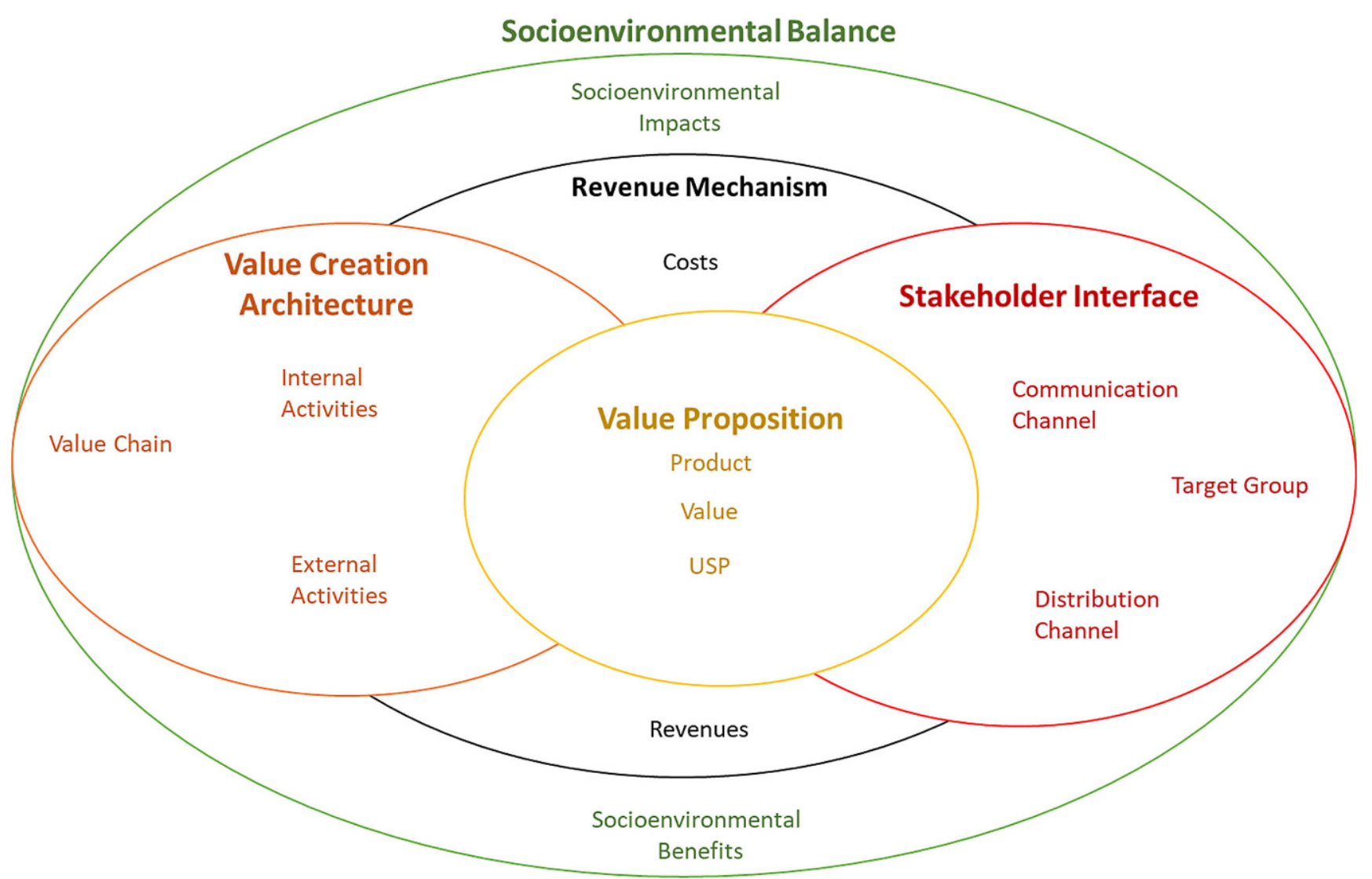

Fig. 3 Sustainable business model canvas. (Source: own illustration)

tured within the enterprise, e.g. reduction of waste streams in production, different allocation of under-used resources, or utilizing reusable components of products (Yang et al. 2017).

To identify the current situation of the business a business model canvas is widely regarded as a helpful and appropriate tool (Osterwalder and Pigneur 2010; Upward and Jones 2016; Joyce and Paquin 2016). The workshop follows this recommendation and thus we incorporate a sustainable business model canvas, building on the classical business canvas (Osterwalder et al. 2005; Osterwalder and Pigneur 2010) and contemporary variations stemming from sustainable business model literature (Upward and Jones 2016; Elkington and Upward 2016; Joyce and Paquin 2016). In general, the four main components reflect the value proposition, value creation, customer interface and revenue mechanism (Schwarz et al. 2013; Boons and Lüdeke-Freund 2013). To emphasize the idea that sustainable business models have to include a wide range of stakeholder (Evans et al. 2017), we opted to rename the customer interface in stakeholder interface emphasizing the importance of integrative stakeholder integration going beyond the narrow customer focus (e.g., NGOs, political parties, nature, etc.). In addition, we added the notion of a socioenvironmental balance that acts as an overarching perspective affecting all main components. As such, it draws attention to the social and environmental impacts and benefits of the business model and also symbolizes the embeddedness of the company in the wider natural environment (e.g., Upward and Jones 2016). The model is shown in Fig. 3. The components are further divided into 13 interrelated sub-blocks. For each sub-block, the participants receive guiding questions to help them to assess their current situations. These questions have been derived from the current business model literature (Osterwalder and Pigneur 2010; Upward and Jones 2016) and are adapted to point the workshop group towards social and environmental challenges in their business model. To give some examples, the sub-blocks include questions concerning the socioenvironmental impact of internal and external activities of value creation, communication channels, target groups, offered values, or the cost and revenue structure (see Table 3 for the sub-blocks and corresponding questions). The canvas is not only used to assess the current situation but also as a guiding tool for the subsequent process.

The business model canvas can provide first impressions and ideas for sustainable business innovation (Upward and Jones 2016; Joyce and Paquin 2016). In addition, business model literature recently proposed the 'value uncaptured' perspective to identify socioenvironmental business oppor- 
Table 4 The 26 main sources of value uncaptured. (Source: own illustration based on Yang et al. 2017)

\begin{tabular}{lll}
\hline Beginning of Life & Middle of Life & End of Life \\
\hline Design, Production Operations manage- & Customers' value uncaptured, Human resources, Operations management, Ser- & Recycle, \\
ment, Customer needs, Human resources, & vice data, Co-products or by-products, Products' products, Services, Customer & Reuse, Re- \\
Contracts, R\&D, Finance, Planning, & needs, Need for a platform, Delivery, Conflicts over service contracts, Risks, & manufacture \\
Knowledge \& technology & Wasted resources and energy & \\
\hline
\end{tabular}

tunities. Yang et al. (2017) utilized a life-cycle perspective and identified 26 main sources of uncaptured value from the beginning to the middle to the end of the product lifecycle (see Table 4). The sources of uncaptured value can act as inspirations for innovating companies to reveal value opportunities that are essential for ELT (Yang et al. 2017). To better illustrate these opportunities, the value mapping approach is recognized as an important avenue in this regard (Bocken et al. 2013). Value mapping can provide a lens to portray value captured, value missed, and value destroyed, which allows to derive socioenvironmental value opportunities (Bocken et al. 2013; Geissdoerfer et al. 2016). Moreover, it answers the need for extensive stakeholder integration of sustainable business modeling (Schaltegger et al. 2016; Evans et al. 2017). Revealing the value opportunities implicitly include the evaluation of the relative improvement of the company's impact, which should be qualitatively elaborated in more detail. The canvas and value mapping are particularly interesting for the entrepreneurial lean approach of the workshop as they are flexible, easy to use, and allow for fast changes and creative solutions (Bocken et al. 2015; Geissdoerfer et al. 2016; Joyce and Paquin 2016).

After passing the first milestone, the first transition phase is used to follow the principle of direct market feedback (Blank 2013a) and to get feedback through interviews or questionnaires from other functional areas within the company.

\subsection{Session 2-Opportunity evaluation}

To evaluate the potential of the opportunities developed in session 1, it is important to understand the influencing factors and the wider social, environmental, and economic embeddedness (Boons and Lüdeke-Freund 2013; Schaltegger et al. 2016; Evans et al. 2017). Systematic observation of the business' environment helps to evaluate opportunities and transfer them into a broader context as well as to identify further stakeholders, which is the main objective in session 2. One examines whether the value opportunities are attractive in relation the macro-environmental context conditions and checks for environmental, technological, and market feasibility.

To portray the current macro-environment of the company, the workshop utilizes a PESTEL (Political, Economic, Socio-cultural, Technological, Environment, and
Legal) analysis. This tool offers the possibility for a qualitative assessment of the circumstances the company is acting within. It can be utilized to identify trends but also to discover hitherto ignored stakeholders such as potential partner firms or customer segments (Yüksel 2012), which is essential for sustainable business modeling. In the workshop, each main category consists of several subcategories which are qualitatively integrated to derive an overarching macro-perspective. The information derived in this step is used to contextualize the opportunities from session 1. A qualitative assessment of the context suits the lean process well, because it offers the possibility for flexible creation, testing and reworking of the assumed conditions and the connection between the macro-environment and the business model opportunity.

Passing the second milestone, the new concepts and learnings are brought outside the company's boundaries. In the transition phase between session 2 and session 3, the ideas are presented to new potential customers, political actors, suppliers, etc. to gain further direct feedback from the wider environment, which can be used to adapt the opportunity.

\subsection{Session 3-Opportunity development through sustainable business model design}

This step aims for the further development of the opportunity through the design of the individual components of the new business model variant. The value opportunities narrowed down in session 2 are picked up and integrated into a comprehensive business model. If necessary, they are supplemented and developed further depending on the fit of the business model components and new insights generated along the creative design process. Only by combining and adjusting the sub-blocks will it eventually be possible to determine whether a competitive advantage can be generated. Depending on the opportunities elaborated in the previous phases, sustainable innovations with improved socioenvironmental benefits relative to previous solutions can be located in each of these sub-elements (e.g. product, processes, distribution). However, it is often the combination of individual components that lead to a unique business model, which is difficult for the competition to imitate due to its complexity (Casadesus-Masanell and Ricart 2007).

The main tool in the third session is the business canvas as already established in session 1 . While the canvas 
Table 5 Business model archetypes to inspire sustainable business model innovation. (Source: own illustration based on Bocken et al. 2014, 2016)

\begin{tabular}{|c|c|c|}
\hline Groupings & Archetypes & Examples \\
\hline \multirow[t]{3}{*}{$\begin{array}{l}\text { Environmental } \\
\text { sustainability }\end{array}$} & $\begin{array}{l}\text { Maximize material and } \\
\text { energy efficiency }\end{array}$ & $\begin{array}{l}\text { Low carbon manufacturing/solutions, lean manufacturing, additive manufacturing, de-materializa- } \\
\text { tion (of products/packaging), increased functionality }\end{array}$ \\
\hline & Create value from waste & $\begin{array}{l}\text { Circular economy, closed loop, industrial symbiosis, reuse/recycle/re-manufacture, take back man- } \\
\text { agement, use excess capacity, sharing assets (shared ownership and collaborative consumption), } \\
\text { extended producer responsibility }\end{array}$ \\
\hline & $\begin{array}{l}\text { Substitute with renew- } \\
\text { ables and natural pro- } \\
\text { cesses }\end{array}$ & $\begin{array}{l}\text { Move from non-renewable to renewable energy sources, solar and wind-power based energy in- } \\
\text { novations, zero emissions initiative, blue economy, biomimicry, natural step, slow manufacturing, } \\
\text { green chemistry }\end{array}$ \\
\hline \multirow[t]{3}{*}{$\begin{array}{l}\text { Social } \\
\text { sustainability }\end{array}$} & $\begin{array}{l}\text { Deliver functionality } \\
\text { rather than ownership }\end{array}$ & $\begin{array}{l}\text { Product-oriented Product Service System (PSS)_-maintenance and extended warranty, use-ori- } \\
\text { ented PSS—rental/lease/share, result-oriented PSS_pay per use }\end{array}$ \\
\hline & Adopt a stewardship role & $\begin{array}{l}\text { Consumer care-promote consumer health and well-being, ethical trade, choice editing by retail- } \\
\text { ers, radical transparency about environmental/social impacts }\end{array}$ \\
\hline & Encourage sufficiency & $\begin{array}{l}\text { Consumer education and communication, demand management, slow fashion, product longevity, } \\
\text { premium branding/limited availability, frugal business }\end{array}$ \\
\hline \multirow[t]{3}{*}{$\begin{array}{l}\text { Economical } \\
\text { sustainability }\end{array}$} & $\begin{array}{l}\text { Repurpose for society/ } \\
\text { environment }\end{array}$ & $\begin{array}{l}\text { Not for profit, hybrid businesses and social enterprises (for profit), alternative ownership: coop- } \\
\text { erative and mutual collectives, social and biodiversity regeneration initiatives, base of pyramid } \\
\text { solutions, localization, home based flexible working }\end{array}$ \\
\hline & $\begin{array}{l}\text { Develop scale up solu- } \\
\text { tions }\end{array}$ & $\begin{array}{l}\text { Collaborative approaches (sourcing and production lobbying), incubators and entrepreneur sup- } \\
\text { port models, licensing and franchising, open innovation (platforms), crowd sourcing/funding, } \\
\text { patient/slow capital collaborations }\end{array}$ \\
\hline & Inclusive value creation & $\begin{array}{l}\text { Collaborative approaches (sourcing, producing, lobbying), peer-to-peer sharing, inclusive innova- } \\
\text { tion, bottom of the pyramid solutions }\end{array}$ \\
\hline
\end{tabular}

was used as an assessment tool for the current situation of the firm before, it now takes the function of a creative device for business model innovation (Fritscher and Pigneur 2010; Joyce and Paquin 2016). Sub-blocks and corresponding questions (Table 3 and Fig. 3) should now be considered from a different perspective and try to creatively alter them corresponding to the value opportunities defined in the earlier steps. Scholars have shown that business canvases can be a strong tool for organizations to craft sustainability-oriented change (Joyce and Paquin 2016; França et al. 2017). To reduce complexity and to prevent stalemate situations, it is advisable to start with one component and follow up with the subsequent linking of the different sub-blocks. This allows for an iterative design of the whole business model (Fritscher and Pigneur 2010; Schwarz et al. 2013).

Further, to gain creative input we propose the utilization of sustainable business models archetypes as put forward by Bocken et al. (2014), which they derived from an extensive literature and practice review. Archetypes provide inspiration for the core components of the business model (Table 5). Overall these tools allow for diverse versions of business models, which can then be compared, discussed, and adapted.

To evaluate the business model designs, a checklist of questions is introduced: Does the new business model design provide relative positive socioenvironmental impact and, if so, in which form and in which component? Has the value opportunity been integrated as intended? Does the sustainable business model fit the external macro-environment derived from session 2? Can the sustainable business model innovation be realized with current corporate skills and resources? Is the sustainable business model attractive for the identified stakeholders?

Approaching milestone 3, the next transition phase and with that the iterative feedback process starts. Getting feedback from internal decision-makers allows for further adaptions so that the projects fits the company's mission and vision. Further, the transition phase offers the possibility to design first prototypes and expose them to customers and stakeholders for beta tests. If applicable, this can drastically enhance the lean thinking design process (Eisenmann et al. 2012).

\subsection{Session 4-Reflection and decision of opportunity exploitation}

Session 4 is dedicated to the last presentation of the workshop results including new information from the transition phase after session 3 . The participants show their final version of a potential business model innovation, which should be implemented. This is their last opportunity to discuss their findings in the workshop setting. This session has the following purpose: First, the group reports and reflects on the lessons learned concerning the innovation process of business modeling, sustainability-oriented design process, and the utilization of ELT. Here, reflection is a key action for more effective learning outcomes (Cope 2003; Pittaway and Thorpe 2012). Second, they should make a final decision about the implementation of their sustainable business model innovation. Therefore, they decide if they will per- 
severe and thus start the implementation within their company, if they will revise the potential innovation project and go back to earlier steps of the innovation process, or if they will allow the idea to perish and stop the whole process.

\section{Discussion}

This article set out to explore how firms can utilize entrepreneurial approaches to develop sustainable business models and overcome the associated challenges. In doing so, we investigated the complementarities of ELT and sustainable business model innovation and designed a workshop. In the following, we discuss this intersection and how the workshop supports opportunities and mitigates pitfalls of ELT for sustainable business model innovation. We, thereby, build on recent work, which identified the main challenges for developing and implementing sustainable business model variants, namely multiple forms of value creation, the mindset of the company, reluctance to allocate resources, and the integration of external stakeholders (Massa et al. 2017; Evans et al. 2017; Lüdeke-Freund and Dembek 2017).

A core challenge of sustainable business modeling is the reconciliation of social, environmental, and commercial logics that each have their own values and goals. This, however, is a necessity to create multiple forms of value (Schaltegger et al. 2016; Gregori et al. 2019). The workshop provides entrepreneurial lean-oriented tools and methods that help to take multiple perspectives and reminds the workshop participants to consider socioenvironmental benefits and impacts when designing the business model. For example, the sustainable business canvas with its guiding questions and the value mapping tool (Bocken et al. 2013) support in detecting economic and socioenvironmental value and illustrate the connection between them. As such, the workshop supports in identifying and finding a balance between potential profits and benefits for sustainability (Stubbs and Cocklin 2008; Evans et al. 2017). A core premise of ELT is the avoidance of waste (Ries 2011; Eisenmann et al. 2012; Blank 2013a). However, as opposed to lean manufacturing, ELT focuses mostly on waste in terms of time, skills, and the passion of people (Ries 2011) leading to challenges of defining the concept of waste in innovation processes (Elnadi et al. 2013). As opposed to the rather narrow concept of waste that is anchored within ELT, we argue that waste can be any process that does not deliver value to the stakeholders. Defining this waste and value can be a rather subjective process. This restriction of ELT can be mitigated by using the business model archetypes (Bocken et al. 2014) and taking the value uncaptured perspective (Yang et al. 2017) presented in the workshop design. These tools provide a profound and empirically tested assistance to identify overlooked forms of value and potential sources of waste.

Further, having the right mindset within the company is a necessity to facilitate business model change. Scholars argue that formal and informal values, beliefs, and rules within businesses as well as long-established business metrics hinder the development and introduction of new business models (Boons and Lüdeke-Freund 2013; Evans et al. 2017) and old habits and routines within the business are often difficult to change (Michalek et al. 2019). Following an entrepreneurial lean mindset promotes experimentation and iterative processes, which are highly supportive for business model innovations (Chesbrough 2003, 2010). As shown, ELT can provide a fitting mindset to realize business model innovation for environmental and economic value. The iterative workshop design based on these principles facilitates the opportunity of the ELT paradigm for sustainable business model innovation. Yet, internalizing the lean principles and fully enact the associated values in conjunction with more thorough social and environmental considerations is not trivial. A lack of knowledge about the entrepreneurial lean paradigm can hinder fast actions and project success (Weissbrod and Bocken 2017). Thus, firms might first need to develop the necessary experimentation capabilities to realize innovations based on entrepreneurial lean approaches successfully. Our guided workshop can mitigate this problem as it helps to establish and teach the participants the necessary entrepreneurial mentality. Especially, the reflection phase supports the participants in memorizing the process, tools, and lean thinking paradigm for future applications within the business. Moreover, firms are often confronted with a reluctance to allocate resources towards business model innovation (Chesbrough 2010; Zott et al. 2011; Evans et al. 2017). In this regard, our workshop can provide an initial impetus for experimentation in a save setting to overcome the inertia to allocate resources towards business model innovation.

Another challenge for sustainable business model innovation is the extensive integration of internal and external stakeholder in the innovation process (Keskin et al. 2013). This not only heightens the complexity due to different goals, values, and ambitions of multiple stakeholders but also increases the communication efforts (Stubbs and Cocklin 2008). In general, the ELT approach is supplementary to this as it supports the early and constant integration of internal and external stakeholder in the innovation process (Ries 2011; Eisenmann et al. 2012). The systematic workshop can reduce the associated complexities and communication efforts or, put differently, supports the participants to make them more manageable. The transition phases between the sessions allow the workshop participants to get direct feedback from important stakeholders within and outside the company's boundaries facilitating feedback loops 
(Ries 2011). Yet 'getting out of the building' can provide a great challenge for innovators unexperienced with ELT (Nirwan and Dhewanto 2015). Starting with internal stakeholders in the first transition phase, brings the participants closer to the notion of comprehensive stakeholder integration and these skills are further developed through transition phase two and three. Hence, the process provides a twofold learning opportunity for participants: first, they learn how to engage with multiple stakeholders and, second, they learn from feedback loops gained from the market, stakeholders, or other information sources in a structured manner.

\section{Implications}

This article argues that, if facilitated by the right tools, the ELT approach provides a well-suited foundation for flexible and fast innovation processes for sustainability. This notion is implied in current work on experimentation capabilities in large organizations (Weissbrod and Bocken 2017; Baldassarre et al. 2017), but has not yet been sufficiently explored to date. With this article, we provide another step in this research area with theoretical and practical implications.

This article contributes to the work on ELT towards sustainable business model innovation in established companies by providing a novel and theoretically grounded framework, which adds to the theoretical conversation of lean approaches for sustainable business modeling (Weissbrod and Bocken 2017; Bocken and Snihur 2019). As such, this is one of the first attempts to combine and identify potential synergies of ELT and sustainable business models to facilitate sustainable innovation and mitigate currently identified challenges of sustainable business modeling.

Further, we contribute the call for more comprehensive and tool-assisted approaches based on ELT to support firms in their quest to innovate their business model towards more sustainable variations (Geissdoerfer et al. 2016; Weissbrod and Bocken 2017). In this vein, this article offers practical implications in providing a structured and theoretically grounded workshop to support the focus on the necessary specifications for sustainable business innovation: a clear stakeholder focus with direct feedback from real-life stakeholders, the identification and transformation of uncaptured value, and the incorporation of social and environmental considerations in every aspect of the business model (Boons and Lüdeke-Freund 2013; Schaltegger et al. 2016; Joyce and Paquin 2016). We integrated the ELT principles (experiment and learn; Blank, 2013a; Cooper, 2014; Ries 2011) as well as state-of-the-art and empirically tested tools from sustainable business model research, which are suitable for a fast and flexible design process based on the notion of hypothesis testing of the entrepreneurial lean approach. There- with, the workshop contributes to improve business models in terms of their socioenvironmental performance and supports firms to comply with legal requirements as well as help them to play their part in addressing the fundamental challenges of sustainability.

\section{Limitations and future research}

This article has certain limitations providing starting points for further research. Although on purpose, this work is conceptual and we, thus, call for more empirical studies focusing on ELT and sustainable business model innovation. Related to this, the workshop design needs to be tested and reworked for different contexts. For example, we propose that besides the utilization of established companies to change their business model or develop a new business model, the entrepreneurship context can be an important addressee for the framework to facilitate sustainable development. Sustainable entrepreneurs are well recognized as agents who tackle social and environmental issues by seizing opportunities and are therefore important drivers for change (Cohen and Winn 2007; Hall et al. 2010; Shepherd and Patzelt 2011; Keskin et al. 2013). We state that our lean-approach can easily be transferred in this context and provide helpful support for entrepreneurs in the early stages of business model design. Future research can build on the presented insights and can further elaborate on the potential advantages and drawbacks of ELT in the context of sustainable business modeling.

Funding Open Access funding provided by University of Klagenfurt

Conflict of interest E.J. Schwarz, P. Gregori, I. Krajger and M.A. Wdowiak declare that they have no competing interests.

Open Access This article is licensed under a Creative Commons Attribution 4.0 International License, which permits use, sharing, adaptation, distribution and reproduction in any medium or format, as long as you give appropriate credit to the original author(s) and the source, provide a link to the Creative Commons licence, and indicate if changes were made. The images or other third party material in this article are included in the article's Creative Commons licence, unless indicated otherwise in a credit line to the material. If material is not included in the article's Creative Commons licence and your intended use is not permitted by statutory regulation or exceeds the permitted use, you will need to obtain permission directly from the copyright holder. To view a copy of this licence, visit http://creativecommons.org/licenses/by/4. $0 /$.

\section{References}

Amit R, Zott C (2001) Value creation in E-business. Strateg Manag J 22:493-520. https://doi.org/10.1002/smj.187

Ardichvili A, Cardozo R, Ray S (2003) A theory of entrepreneurial opportunity identification and development. J Bus Ventur 18:105-123. https://doi.org/10.1016/S0883-9026(01)00068-4 
Baldassarre B, Calabretta G, Bocken NMP, Jaskiewicz T (2017) Bridging sustainable business model innovation and user-driven innovation: a process for sustainable value proposition design. J Clean Prod 147:175-186. https://doi.org/10.1016/j.jclepro.2017.01.081

Baumgartner RJ, Rauter R (2017) Strategic perspectives of corporate sustainability management to develop a sustainable organization. J Clean Prod 140:81-92. https://doi.org/10.1016/j.jclepro.2016. 04.146

Belz FM, Binder JK (2015) Sustainable entrepreneurship: a convergent process model. Bus Strateg Environ 26:1-17. https://doi.org/10. 1002/bse. 1887

Birkin F, Cashman A, Koh SCL, Liu Z (2009a) New sustainable business models in China. Bus Strateg Environ 18:64-77. https://doi. org $/ 10.1002 /$ bse. 568

Birkin F, Polesie T, Lewis L (2009b) A new business model for sustainable development: an exploratory study using the theory of constraints in Nordic organizations. Bus Strateg Environ 18:277-290. https://doi.org/10.1002/bse.581

Blank S (2013a) Why the lean start-up changes everything. Harv Bus Rev 91:63-72

Blank S (2013b) The four steps to the epiphany: successful strategies for products that win, 2nd edn. K\&S Ranch Publishing, San Francisco

Bocken N, Snihur Y (2019) Lean startup and the business model: experimenting for novelty and impact. Long Range Plann Press. https://doi.org/10.1016/j.lrp.2019.101953

Bocken N, Short S, Rana P, Evans S (2013) A value mapping tool for sustainable business modelling. Corp Gov Int J Bus Soc 13:482-497. https://doi.org/10.1108/CG-06-2013-0078

Bocken NMP, Rana P, Short SW (2015) Value mapping for sustainable business thinking. J Ind Prod Eng 32:67-81. https://doi.org/10. 1080/21681015.2014.1000399

Bocken NMP, Short SW, Rana P, Evans S (2014) A literature and practice review to develop sustainable business model archetypes. J Clean Prod 65:42-56. https://doi.org/10.1016/j.jclepro.2013.11. 039

Bocken NMP, Weissbrod I, Tennant M (2016) Business Model Experimentation for Sustainability. In: Setchi R, Howlett R, Liu Y, Theobald P (eds) Sustainable Design and Manufacturing 2016. SDM 2016. Smart Innovation, Systems and Technologies, vol 52. Springer, Cham, pp 297-306. https://doi.org/10.1007/978-3-31932098-4_26

Boons F, Lüdeke-Freund F (2013) Business models for sustainable innovation: state-of-the-art and steps towards a research agenda. J Clean Prod 45:9-19. https://doi.org/10.1016/j.jclepro.2012.07. 007

Burgelman RA (1983) A process model of internal corporate venturing in the diversified major firm. Adm Sci Q 28:223. https://doi.org/ $10.2307 / 2392619$

Casadesus-Masanell R, Ricart JE (2007) Competing through business models

Chesbrough H (2010) Business model innovation: opportunities and barriers. Long Range Plann 43:354-363. https://doi.org/10.1016/ j.lrp.2009.07.010

Chesbrough HW (2003) Open innovation: the new imperative for creating and profiting from technology. Harvard Business School Press, Boston

Cohen B, Winn MI (2007) Market imperfections, opportunity and sustainable entrepreneurship. J Bus Ventur 22:29-49. https://doi.org/ 10.1016/j.jbusvent.2004.12.001

Cooper RG (1990) Stage-gate systems: a new tool for managing new products. Bus Horiz 33:44-54. https://doi.org/10.1016/00076813(90)90040-I

Cooper RG (2014) What's next?: after stage-gate. Res Manag 57:20-31. https://doi.org/10.5437/08956308X5606963

Cooper RG, Edgett SJ, Kleinschmidt EJ (2002) Optimizing the stagegate process: what best-practice companies do-I. Res Manag 45:21-27. https://doi.org/10.1080/08956308.2002.11671518
Cope J (2003) Entrepreneurial learning and critical reflection. Manag Learn 34:429-450. https://doi.org/10.1177/1350507603039067

Dangelico RM, Pontrandolfo P (2015) Being "green and competitive": the impact of environmental actions and collaborations on firm performance. Bus Strateg Environ 24:413-430. https://doi.org/10. 1002/bse. 1828

Davies IA, Chambers L (2018) Integrating hybridity and business model theory in sustainable entrepreneurship. J Clean Prod 177:378-386. https://doi.org/10.1016/j.jclepro.2017.12.196

Eisenmann TR, Ries E, Dillard S (2012) Hypothesis-driven entrepreneurship: the lean startup. Entrep Manag Case No 812095. Harvard Bus Sch, Harvard, pp 1-26

Elkington R, Upward A (2016) Leadership as enabling function for flourishing by design. J Glob Responsib 7:126-144. https://doi. org/10.1108/JGR-01-2016-0002

Elnadi M, Shehab E, Peppard J (2013) Challenges of lean thinking application in product-service system. In: Proceedings of the 11th international conference on manufacturing research (ICMR2013). Cranfield University, UK, pp 461-466

European Commission (2013) Factories of the future: multi-annual roadmp for the contractural PPP under horizon 2020

Evans S, Vladimirova D, Holgado M et al (2017) Business model innovation for sustainability: towards a unified perspective for creation of sustainable business models. Bus Strateg Environ 26:597-608. https://doi.org/10.1002/bse.1939

Foss NJ, Saebi T (2017) Fifteen years of research on business model innovation. J Manage 43:200-227. https://doi.org/10.1177/ 0149206316675927

França CL, Broman G, Robèrt K-H et al (2017) An approach to business model innovation and design for strategic sustainable development. J Clean Prod 140:155-166. https://doi.org/10.1016/j. jclepro.2016.06.124

Fritscher B, Pigneur Y (2010) Supporting business model modelling: a compromise between creativity and constraints. In: England D, Palanque P, Vanderdonckt J, Wild PJ (eds) Task Models and Diagrams for User Interface Design. TAMODIA 2009. Lecture Notes in Computer Science, vol 5963. Springer, Berlin, Heidelberg, pp 28-43. https://doi.org/10.1007/978-3-642-11797-8_ 3

Gast J, Gundolf K, Cesinger B (2017) Doing business in a green way: a systematic review of the ecological sustainability entrepreneurship literature and future research directions. J Clean Prod 147:44-56. https://doi.org/10.1016/j.jclepro.2017.01.065

Geissdoerfer M, Bocken NMP, Hultink EJ (2016) Design thinking to enhance the sustainable business modelling process-a workshop based on a value mapping process. J Clean Prod 135:1218-1232. https://doi.org/10.1016/j.jclepro.2016.07.020

Ghezzi A, Cavallo A (2020) Agile business model innovation in digital entrepreneurship: lean startup approaches. J Bus Res 110:519-537. https://doi.org/10.1016/j.jbusres.2018.06.013

Gregori P, Holzmann P (2020) Digital sustainable entrepreneurship: a business model perspective on embedding digital technologies for social and environmental value creation. J Clean Prod 272:122817. https://doi.org/10.1016/j.jclepro.2020.122817

Gregori P, Wdowiak MA, Schwarz EJ, Holzmann P (2019) Exploring value creation in sustainable entrepreneurship: insights from the institutional logics perspective and the business model lens. Sustainability 11:2505. https://doi.org/10.3390/su11092505

Gremyr I, Fouquet J (2012) Design for Six Sigma and lean product development. Int J Lean Six Sigma 3:45-58. https://doi.org/10. 1108/20401461211223722

Hall JK, Daneke GA, Lenox MJ (2010) Sustainable development and entrepreneurship: past contributions and future directions. J Bus Ventur 25:439-448. https://doi.org/10.1016/j.jbusvent.2010.01. 002

Hansen EG, Grosse-Dunker F, Reichwald R (2009) Sustainability innovation cube - $\mathrm{a}$ framework to evaluate sustainability-oriented 
innovations. Int J Innov Manag 13:683-713. https://doi.org/10. $1142 / \mathrm{S} 1363919609002479$

Hindle K (2010) Skillful dreaming: testing a general model of entrepreneurial process with a specific narrative of venture creation. In: Gartner WB (eds) Entrepreneurial narrative: theory, ethnomethodology and reflexivity. Clemson University Digital Press, Clemson, pp 101-139

Hockerts K, Wüstenhagen R (2010) Greening Goliaths versus emerging Davids - theorizing about the role of incumbents and new entrants in sustainable entrepreneurship. J Bus Ventur 25:481-492. https://doi.org/10.1016/j.jbusvent.2009.07.005

Holzmann P, Breitenecker RJ, Soomro AA, Schwarz EJ (2017) User entrepreneur business models in 3D printing. J Manuf Technol Manag 28:75-94. https://doi.org/10.1108/JMTM-12-2015-0115

Hope A (2018) Sustainable business model design: a review of tools for developing responsible business models. In: Moratis L, Melissen F, Idowu S (eds) Sustainable business models. CSR, sustainability, ethics \& governance. Springer, Cham, pp 377-394

Humble M, O’Reilly B, Molesky J (2014) Lean enterprise: how high performance organizations innovate at scale. O'Rilley Media, Sebastopol

Joyce A, Paquin RL (2016) The triple layered business model canvas: a tool to design more sustainable business models. J Clean Prod 135:1474-1486. https://doi.org/10.1016/j.jclepro.2016.06.067

Keskin D, Diehl JC, Molenaar N (2013) Innovation process of new ventures driven by sustainability. J Clean Prod 45:50-60. https:// doi.org/10.1016/j.jclepro.2012.05.012

Keskin D, Wever R, Brezet H (2020) Product innovation processes in sustainability-oriented ventures: a study of effectuation and causation. J Clean Prod 263:1-31. https://doi.org/10.1016/j.jclepro. 2020.121210

Kurucz EC, Colbert BA, Lüdeke-Freund F et al (2017) Relational leadership for strategic sustainability: practices and capabilities to advance the design and assessment of sustainable business models. J Clean Prod 140:189-204. https://doi.org/10.1016/j.jclepro. 2016.03.087

Laasch O (2018) Beyond the purely commercial business model: organizational value logics and the heterogeneity of sustainability business models. Long Range Plann 51:158-183. https://doi.org/ 10.1016/j.lrp.2017.09.002

Ladd T (2018) Does the business model canvas drive venture success? J Res Mark Entrep 20:57-69. https://doi.org/10.1108/JRME-112016-0046

Lüdeke-Freund F, Dembek K (2017) Sustainable business model research and practice: emerging field or passing fancy? J Clean Prod 168:1668-1678. https://doi.org/10.1016/j.jclepro.2017.08.093

Massa L, Tucci CL, Afuah A (2017) A critical assessment of business model research. Acad Manag Ann 11:73-104. https://doi.org/10. 5465/annals.2014.0072

Michalek G, Thronicker I, Yildiz Ö, Schwarze R (2019) Habitually green: integrating the concept of habit into the design of pro-environmental interventions at the workplace. Sustain Manag Forum. https://doi.org/10.1007/s00550-019-00487-9

Moroz PW, Hindle K (2012) Entrepreneurship as a process: toward harmonizing multiple perspectives. Entrep Theory Pract 36:781-818. https://doi.org/10.1111/j.1540-6520.2011.00452. $\mathrm{x}$

Nepal BP, Yadav OP, Solanki R (2011) Improving the NPD process by applying lean principles: a case. Study Eng Manag J 23:52-68. https://doi.org/10.1080/10429247.2011.11431886

Nirwan MD, Dhewanto W (2015) Barriers in implementing the lean startup methodology in Indonesia - case study of B2B startup. Procedia Soc Behav Sci 169:23-30. https://doi.org/10.1016/j. sbspro.2015.01.282

Osterwalder A, Pigneur Y (2010) Business model generation: a handbook for visionaries, game changers, and challengers. Wiley, Hoboken
Osterwalder A, Pigneur Y, Tucci CL (2005) Clarifying business models: origins, present, and future of the concept. Commun Ais 15: $1-40$

Owens T, Fernandez O (2014) The lean enterprise: how corporations can innovate like startups. John Wiley \& Sons, Inc, New Jersey

Palzkill A, Augenstein K (2017) Business model resilience-understanding the role of companies in societal transformation processes. uwf 25:61-70. https://doi.org/10.1007/s00550-017-04583

Phan PH, Wright M, Ucbasaran D, Tan W-L (2009) Corporate entrepreneurship: current research and future directions. J Bus Ventur 24:197-205. https://doi.org/10.1016/j.jbusvent.2009.01.007

Pittaway L, Thorpe R (2012) A framework for entrepreneurial learning: a tribute to Jason Cope. Entrep Reg Dev 24:837-859. https://doi. org/10.1080/08985626.2012.694268

Rana P, Short SW, Evans S et al (2017) Toolset for sustainable business modelling. In: Liyanage J, Uusitalo T (eds) Value networks in manufacturing. Springer series in advanced manufacturing. Springer, Cham, pp 123-153

Ries E (2011) The lean startup. Crown Publishing, New York

Ritala P, Huotari P, Bocken N et al (2018) Sustainable business model adoption among S\&P 500 firms: a longitudinal content analysis study. J Clean Prod 170:216-226. https://doi.org/10.1016/j. jclepro.2017.09.159

Sammut-Bonnici T, Galea D (2015) PEST analysis. In: Wiley encyclopedia of management. John Wiley \& Sons, Ltd, Chichester, UK, pp 1-1

Schaltegger S, Hansen EG, Lüdeke-Freund F (2016) Business models for sustainability: origins, present research, and future avenues. Organ Environ 29:3-10. https://doi.org/10.1177/1086026615599 806

Schultz C, Globocnik D, Kock A, Salomo S (2018) Application and performance impact of stage-gate systems - the role services in the firm's business focus. R\&d Manag. https://doi.org/10.1111/ radm. 12341

Schwarz EJ, Krajger I, Dummer R (2013) Von der Geschäftsidee zum Markterfolg: Das Management von Innovationen in Gründungsund Wachstumsunternehmen, 2nd edn. Linde, Vienna

Shane S, Venkataraman S (2000) The promise of enterpreneurship as a field of research. Acad Manag Rev 25:217. https://doi.org/10. 2307/259271

Shepherd DA, Patzelt H (2011) The new field of sustainable entrepreneurship: studying entrepreneurial action linking "what is to be sustained" with "what is to be developed.". Entrep Theory Pract 35:137-163. https://doi.org/10.1111/j.1540-6520.2010. 00426.x

Sneddon C, Howarth RB, Norgaard RB (2006) Sustainable development in a post-Brundtland world. Ecol Econ 57:253-268. https:// doi.org/10.1016/j.ecolecon.2005.04.013

Sommer A (2012) Managing green business model transformations. Springer, Berlin, Heidelberg

Stubbs W, Cocklin C (2008) Conceptualizing a "sustainability business model.”. Organ Environ 21:103-127. https://doi.org/10. $1177 / 1086026608318042$

Sugimori Y, Kusunoki K, Cho F, Uchikawa S (1977) Toyota production system and Kanban system materialization of just-in-time and respect-for-human system. Int J Prod Res 15:553-564. https://doi. org/10.1080/00207547708943149

Teece DJ (2010) Business models, business strategy and innovation. Long Range Plann 43:172-194. https://doi.org/10.1016/j.lrp. 2009.07.003

Tesch JF, Brillinger A-S, Bilgeri D (2017) Internet of things business model innovation and the stage-gate process: an exploratory analysis. Int J Innov Manag 21:1740002. https://doi.org/10.1142/ S1363919617400023

Tomy S, Pardede E (2017) Opportunity evaluation using uncertainties in software entrepreneurship. Entrep Res J 7:1-16. https://doi.org/ 10.1515/erj-2016-0044 
United Nations (2015) Transforming our world: the 2030 agenda for sustainable development (Resolut Adopt by Gen Assem 25 September 2015, A/RES/70/1)

Upward A, Jones P (2016) An ontology for strongly sustainable business models. Organ Environ 29:97-123. https://doi.org/10.1177/ 1086026615592933

Weissbrod I, Bocken NMP (2017) Developing sustainable business experimentation capability-a case study. J Clean Prod 142:2663-2676. https://doi.org/10.1016/j.jclepro.2016.11.009

Yadav OP, Nepal BP, Jain R (2007) Managing product development process complexity and challenges: a state-of-the art review. J Des Res 6:487. https://doi.org/10.1504/JDR.2007.016853

Yang M, Evans S, Vladimirova D, Rana P (2017) Value uncaptured perspective for sustainable business model innovation. J Clean Prod 140:1794-1804. https://doi.org/10.1016/j.jclepro.2016.07.102
Yüksel I (2012) Developing a multi-criteria decision making model for PESTEL analysis. Int J Bus Manag. https://doi.org/10.5539/ijbm. v7n24p52

Zacho KO, Mosgaard M, Riisgaard H (2018) Capturing uncaptured values - a Danish case study on municipal preparation for reuse and recycling of waste. Resour Conserv Recycl 136:297-305. https://doi.org/10.1016/j.resconrec.2018.04.031

Zott C, Amit R, Massa L (2011) The business model: recent developments and future research. J Manage 37:1019-1042. https://doi. org/10.1177/0149206311406265 